\title{
Ahkâm Hadislerinde Psikolojik Etmenler: Regl Dönemindeki Talâk Üzerine Bir İnceleme*
}

\author{
Prof. Dr. Nasi ASLAN**
}

Atıf / @-- Aslan, N. (2017). Ahkâm Hadislerinde Psikolojik Etmenler: Regl Dönemindeki Talâk Üzerine Bir İnceleme, Çukurova Üniversitesi Illahiyat Fakültesi Dergisi, 17 (1), 21-38.

Öz- İslam dini insanları dünya ve âhiret saadeti için doğru yola ulaştırmak amacıyla Allah tarafından indirilmiş bir din olup koyduğu hükümlerde hikmeti gözetmiştir. Bu hikmet gereği insanlara dinî mükellefiyetler yüklenirken, muhatabın maddî-manevî bütün yönleri göz önünde bulundurulmuştur. Insanın manevî yönünün başında, hatta olaylara bakış açısını da şekillendiren en önemli yönü psikolojisidir. Kur'ân, insan psikolojisini dikkate alarak nâzil olduğu gibi, Hz. Peygamber de hadislerde bu yönü ihmal etmemiştir. Hz Peygamber, "Hiç bir hâkim öfkeli haldeyken hüküm veremez/vermesin!" buyurarak hâkimin hüküm vermede uyması gereken bir ilkeye işaret etmektedir. O ilke, hâkimin sakin ve soğukkanlı olduğu yani duygusal bazı hislerin tesiri altında olmadığı durumda muhakeme yapmasıdır. İslâm hukukçuları da zikredilen hadisi delil alarak öfkeli hale ilaveten hâkimin şiddetli açlık, susuzluk, uykusuzluk, üzüntü ve hastalık durumlarında da hüküm vermesinin uygun olmayacağını ifade etmişlerdir. Hâkimin bazı olumsuz psikolojik hallerinin yargı faaliyetine olumsuz yansımaması noktasında gözetilen makâsıd, psikolojisi bozukken talak tasarrufunda bulunan kimsenin tasarrufunun geçerli olmaması noktasında da gözetilmiştir. Her ne kadar regl döneminde vaki olan talakın geçerliliği konusunda ulema ihtilaf etse de bunun sünnete aykırı bid'at bir uygulama olduğu hususunda görüş birliği içinde olmaları burada da makâsıdın gözetildiğini göstermektedir. Bu makalede nasslarda kadınların özel halleri ile ilgili hükümler verilirken, kadınların içinde bulunduğu ruhsal, psikolojik durumlarının dikkate alındığı örnekler üzerinden tartışılmaktadır.

Anahtar sözcükler: Ahkâm hadisleri, psikolojik etmen, talak, hayız, regl, iddet, hikmet

\section{$\S \S \S$}

Makalenin gelişi: 13.10.2016; Yayına kabul tarihi: 19.06.2017

* Bu makale 7-10 Ekim 2015 tarihlerinde Adana'da yapılan Uluslararası İslam ve Tıp (Tıbb-ı Nebevî) Kongresi'nde sunulan tebliğin geliştirilmiş halidir.

** Çukurova Ü. İlahiyat F. İslâm Hukuku Anabilim Dalı, e-posta: nasiaslan@cu.edu.tr 


\section{Giriş}

Araştırma başlığında "psikolojik etmenler" derken derin psikolojik analizleri kastetmiyoruz ve buna girmemiz de branş gereği sınırlarımızı aşar. Bundan kastımız ilahi hitab çerçevesinde şerîi hükümlere muhatap olan mükellefin, gerek ayetler gerekse ahkâm hadislerinde psikolojik durumunun dikkate alınması meselesidir. Bu şekilde bütün ahkâm ayetleri ve hadislerin taramaya tabi tutularak incelenmesi başlı başına bir araştırmayı gerektirir. $\mathrm{Bu}$ nedenle biz meseleyi, konuyla doğrudan ilgili birkaç örnek üzerinden tartışmakla birlikte asıl, kadınların regl/adet döneminde gerçekleşen boşanma üzerinde duracağız.

Bilindiği üzere İslam hukukunun beşeri hukuk sistemlerine nispetle temayüz ettiği en belirgin vasfı hiç şüphesiz ki onun vahiy kaynaklı olmasıdır. Zira İslami öğretide hükmün kaynağı hakimü'ı-mutlak, aşkın varlık olan Allah Teâlâ'dır. Bu, epistemolojik bağlamda böyle olduğu gibi dinin vâdı'ı bağlamında (emir ve yasakları içeren normatif kuralları koyması açısından) da Yüce Allah, Şâri vasfıyla muttasıftır. Âlîm olan ve ilmiyle kullarının dinî ve dünyevî maslahatlarını en iyi bilen Yüce Allah, hakîm olarak onlarla ilgili koyduğu hükümlerde de en ince hikmeti gözetmiştir. Yüce Allah'ın hikmeti gereği, kullarının maddî ve manevî maslahatlarını gözetirken onların psikolojik durumlarını da dikkate almış olması bu kapsamda değerlendirilebilir. Kendini yalnız hisseden mü'mine dost, yardımcı ve vekil olarak Allah'ın kâfî geleceğini bildiren ayetlerde ${ }^{1}$ bu açıkça görülür. Pratiğe dönük ahkâm ayetlerinde şer'î hitap ile muhatap olan kulun psikolojisinin de dikkate alınması yine hikmet gereğidir. Allah'ın kelamı olan Kur'an'da hikmetin gözetildiği gibi, ahkâm hadislerinde yine kulların her türlü maslahatını muhtevi hikmet gözetilmiş ve buna bağlı olarak psikolojik etmenler dikkate alınmıştır. Zira norm koyucu hükümleri içeren ahkâm hadisleri de vahiy kaynaklı olup dinî nasslar kapsamında mülahaza edilir.

Genelde İslam âlimlerine özelde usul bilginlerine göre Hz. Peygamberden dini beyan sadedinde sadır olan sözler vahiy kapsamındadır. Çünkü beyan onun asli görevlerinden birdir. Kur'anda "...insanlara kendilerine indirileni açıklaman için ve düşünüp anlasınlar diye sana da Kur'ân'ı indirdik."2 buyrulması buna açıkça delalet eder. Burada söz konusu hadislerin, insan psikolojisini dikkate alan tavrı onun vahiy kaynaklı olması yönüyle doğrudan

1 Bkz. Âl-i İmrân, 3/173; Enfâl 8/40; Hac, 22/78.

2 Nahl, 16/44. 
ilintili olmasa da; Yüce Allah'ın Hz. Peygamberi onun muhataplarının durumları ve içinde bulunduğu gerçeklikleri dikkate alacak bir donanımda teçhiz etmesi ve eğitmesi uzak bir ihtimal olmasa gerek.

Biz asıl meseleye geçmeden önce konuya ilgi çekmek için âlimlerin cumhuru tarafından aynı/yakın manada anlaşılmış bir kaç örnek üzerinde duracağız.

\section{Ahkâm Hadislerinde Psikolojik Etmenlere Dair Örnekleme}

\section{1. Öfke Halinde Bulunan Bir Hâkimin Hüküm Vermesi/Vermemesi}

Öfke anında insanın mantıklı düşünme yeteneğinin geçici olarak bloke edildiği akl-ı selim düşünme sürecinin oluşumunun sekteye uğradığı, beynin yargılama ile ilgili bölümünün sağlıklı çalışmadığı bilinmektedir. Aklın ve iradenin etkisinden çıkan, öfke heyecanının yönlendirmesi ile hareket etmeye başlayan bir hâkimin/yargıcın yargılama yapması Hz. Peygamber tarafından doğru bulunmamıştır. Hz. Peygamberin bu açıklaması aynı zamanda öfke heyecanının akıl ve irade üzerinde oluşturduğu olumsuz tesirleri de ortaya koymaktadır. ${ }^{3}$

"Öfkeli olduğun zaman iki kişi arasında hüküm verme"4 Bu hadis, öfkenin insan üzerindeki etkisi hakkında yeterince ipucu vermektedir. Öfkelenmek, bir tür sarhoşluk ve cinnet halidir. Kızgınlık halinde bilginin değerlendirildiği kalp, düşüncenin kaynağı olan zihin öfkenin tesiri altında kalır. Böyle menfi bir etkinin altına giren kalp ve zihinden erdem ve adalet içeren kararın ya da hükmün çıkması mümkün olmaz. ${ }^{5}$

Bu itibarla hâkim, yargılama faaliyetinde bulunacağı zaman, mutedil ve sakin bir halde olmalı ki adil bir karar verebilsin. Dolayısıyla onun sağlıklı düşünüp doğru karar vermesine engel olacak her türlü psikolojik etmenlerden uzak bulunması gerekir. Hz. Peygamber, yargıçlık görevini îfa edecek hakimin hüküm vermede uyması gereken bir ilke bağlamında, "Hiç bir hâkim öfkeli

3 Kasapoğlu, Abdurrahman, “Kur'an'da Adalet Psikolojisi-Adaleti Engelleyen Psiko Sosyal Faktörler-" Hikmet Yurdu Dergisi, sayı: 10, -www.hikmetyurdu.com- 2012, s. 95.

4 Buhârî, Ebû Abdullah Muhammed b. İsmail, Sahîhu'l-Buhârî, nşr. Halil b. Me'mun Şiha, Daru'l-Marife, Beyrut 2010, Ahkâm,13.

5 Aydın, Hayati, Kur'an'da İnsan Psikolojisi, Timaş Yayınları, İstanbul, 1999, s.116. 
haldeyken hüküm veremez/ vermesin."6 buyurmaktadır. İslâm hukukçuları, bu hadisi delil alarak hâkimin şiddetli açlık, susuzluk, uykusuzluk, üzüntü ve hastalık durumlarında hüküm vermesinin uygun olmayacağı sonucuna ulaşmışlardır. ${ }^{7}$ Âlimler söz konusu hadisteki illeti dikkate alarak hâkimin psikolojisini etkileyebilecek benzer faktörleri de buna dahil ederek hükmün kapsamını genişletmişlerdir. Bu cümleden olarak olumsuz duyguların veya eşinden uzun süre ayrı kalmış olmasından kaynaklı arzuların tesirinde iken ya da aşırı soğuk ve sıcak ortamda da hüküm vermekten kaçınması gerektiğini belirtmişlerdir. ${ }^{8}$

Zira hakim için duygu durum bozukluklarına ve dikkatinin dağılmasına ya da duygusal davranmasına neden olabilecek bütün psikolojik etkenler onun adil hüküm vermesine engel olabilecek sakıncalar kapsamında değerlendirilmiştir. ${ }^{9}$

Fakihlerce, hakimin doğru düşünebilmesi açısından zihinsel ve ruhsal yapısını etkileyecek her türlü olumsuz tesirden uzak bulunması gerektiği görüşü ortak bir kanaat olarak tezahür eder. Netice olarak yukarıda belirttiğimiz gibi hâkimin içinde bulunduğu psikolojik haller ve bunun yargı faaliyetine olumsuz yansımaması noktasında gözetilen bu maslahat, psikolojik durumu bozukken talak tasarrufunda bulunan kimsenin tasarrufunun geçerli olmaması noktasında da gözetilmiş midir? Şimdi bunun üzerinde durmak istiyoruz.

\section{2.Öfke Anında Gerçekleşen Talâk/Boşama}

Öfkeliyken soğukkanlıığını kaybeden insanın değerlendirme yeteneğini yitirdiği, doğruyla yanlışı birbirinden ayırt etme yeteneğinden yoksun kaldığı ve muhakeme gücünü kaybettiği bilinmektedir. ${ }^{10}$

6 Buhârî, Ahkâm,13; Ebû Dâvûd, Süleyman b. Eş'as, es-Sicistani, Sünenu Ebî Davud, nşr. İzzet Ubeyd ed-De'as, Muhammed Ali es-Seyyid, Dâru' İbni Hazm, Beyrut, 1997, Akdıye, 9.

7 Aslan, Nasi, İslam Hukukunda Yargılama Etiği Illkeleri, Karahan Kitabevi, Adana 2014, s.57,58.

8 Kelvezânî, Mahfuz b. Ahmed, el-Hidâye fi Furûi'l-Fıkhi'l-Hanbeli, Dâru'l-Kütübi'lİlmiye, Beyrut, 2002, c. II, s. 173; İbn Kudâme, Ebû Muhammed Muvaffakuddîn Abdullah b. Ahmed, el-Muğni, nşr. Abdullah b. Abdülmuhsin Türkî, Abdülfettâh Muhammed el-Hulv, Dâru Âlemi'I-Kütüb, Riyad, 1999, c. XIII, s. 439; Bilmen, Ömer Nasuhi, Hukuk-i İslamiye ve Istılâh-ı Fıkhiye Kamusu, Bilmen Yayınları, İstanbul 1970, c. VIII, s. 224.

9 İbn Mâze, Hüsamüddîn, Kitâbu Şerh-i Edebi'l-Kâdî li'l-Hassâf, Bağdat 1977, c. I, s. 340-342.

10 Bkz. Kasapoğlu, "Kur'an'da Adalet Psikolojisi” s. 95. 
Öfke insanın benliğini sardığında, bilgi ve irade yeteneği perdelenir, birey kişi, ne söylediğini, ne istediğini bilemez hale gelir. Gazap hali kişiye öyle tesir eder ki, akıl devre dışı kalır. Şüphesiz böyle durumdaki bir kişi doğru ve tutarlı sözler sarf edemez. ${ }^{11}$

Bu nedenle Hz. Peygamber, "Iğlak/aşırı öfke halinde boşama ve azad yoktur." 12 diyerek öfke ve sinir krizi halindeki boşamayı geçersiz saymıştır. Hadiste geçen "iğlak" kelimesini, İmam Şâfî, Ahmed b. Hanbel, Mâlikî imamlardan Kadı İsmail b. İshak Mesruk ve Ebû Dâvûd gibi birçok âlim "gazap" olarak tefsir etmişlerdir. ${ }^{13} \mathrm{Bu}$ anlam verildiğinde Hz. Peygamber, bu tutumuyla mükellefin psikolojik durumunun hukuki tasarruf üzerindeki etkisine dikkat çekmiştir. Hadiste yer alan "iğlak" kelimesini bazı fakihler "ikrâh" olarak anlamışlardır. İbn Teymiyye de "iğlak" kelimesini kişinin basiretinin kapanarak, sözün maksadını tayin edememesi ve onu bilememesi, sanki maksadı ve iradesi kapanmış gibi olması şeklinde açıklar. ${ }^{14}$ "Iğlak”, dilde kapamak kilitlemek demektir. ${ }^{15}$ Kızgınlık esnasında kişinin salim düşünme kapısı kapanır. Bu durum onun psikolojisini etkiler. Kızan kimsenin aklı karışır istemediği şeyi söyler. İkrah ve sarhoşluk durumunda olduğu gibi temyiz durumu ortadan kalkması nedeniyle öfkeli şahsın talakı bazı âlimlerce muteber kabul edilmez. Burada öfkeli şahıstan maksat "medhûş" (dehşet içindeki) ya da "ğadbân" (hiddetlenmiş) diye ifade edilen aklı başından gitmiş sinir krizi içindeki bulunan

11 Ahmed Abdurrahman, Kızma, Çev. Seyfullah Erdoğmuş, Polen Yayınları, İstanbul 2006, s.19.

12 Ahmed b. Hanbel, Ebû Abdullâh Ahmed b. Muhammed eş-Şeybânî, Müsnedü'lİmâm Ahmed b. Hanbel, thk. Şuayb el-Arnaut-Âdil Mürşid, Müessesetü'r-Risâle, Beyrut 1995-2001, c. XXXXIII, s. 378 (26360); İbn Mâce, Ebû Abdullâh Muhammed b. Yezîd el-Kazvînî, Sünenü ibni Mâce, Dâru's-Selâm, Riyâd 1999, Talâk 16 (2046); Ebû Dâvud, Talâk 8 (2193); Dârekutnî, Alî b. Ömer, Sünenü'd-Dârekutnî, thk. Şuayb el-Arnaut ve dğr. Müessesetü'r-Risâle, Beyrut 2004, c. V, s. 65-66 (3988-3999).

13 Ebû Dâvûd, Talâk, 8; İbn Kayyim, Ebû Abdullah Şemseddin Muhammed, Zâdu'lMeâd fi Hayri'I-Ibâd, nşr. Şuayb el-Arnaut, Kuveyt: Mektebetü'l-Menâri'l-İslâm, 1994 , c. V, s. 214.

14 İbn Kayyim, Zâdu'l-Meâd, c. V, s. 215.

15 Meşhur dil âlimi Halil b. Ahmed (ö. 175/791) “ihtedde fülân fe neşibe fî hiddetihî fe ğalega ey gadibe"/ falan hiddetlendi ve hiddetinden kükredi ve kilitlendi yani öfkelendi" ibaresi ile "iglâk" lafzının türediği sözcük olan "ğalega" fiiline bu örnekte "gazap" anlamı vermiş, "iğlâk" kelimesine ise temas etmemiştir. Buradaki manâ kişinin hiddetiyle kendini bir nevi kilitlemesi ve iletişim kanallarını kapatması şeklinde anlaşılabilir. Bkz. Halil, Ebû Abdirrahmân b. Ahmed b. Amr b. Temim elFerâhidî (el-Fürhûdî) Kitâbü'l-ayn, thk. Abdulhamîd Hindâvî, Dâru'l-Kütübi'lİlmiyye, Beyrut 2000, c. V, s. 386. 
kimsedir. Bunda da ölçü, bu durumda olan kimsenin hal ve hareketlerinin ciddi ya da gayri ciddi olduğu ayırt edilemeyecek şekilde iç içe girmesi ve rutinin dışına çıkarak söz ve davranışlarında bozukluğun görülmesidir. Bu sırada o kimsenin akli fonksiyonları yerinde olsa bile öfke durumu, kişinin hissî ve sübjektif bir karar almasına neden olmaktadır. ${ }^{16}$

\section{Kadının Âdet/Regı Döneminde Boşanması}

Kur'ân ve sünnette boşanma konusu ayrıntılı bir şekilde yer almış, bu husus belli ilke ve esaslara bağlanmıştır. Hepsinden de önemlisi boşanan eşlerin bu süreci en az ruhsal zararla atlatabilmeleri için belli yöntemler önerilmiştir. Boşanmanın üç aşamalı olarak belirlenmesi dolayısıyla eşleri boşanmadan vaz geçirecek şart ve ortamların hazırlanması tavsiye edilmiştir. Bu üç aşamalı süreç, tarafların hatalarının telafisine imkân sağlayarak evliliğe yeniden dönüş olarak değerlendirilebilir. Bu sürecin sonunda eğer eşler boşanmaya karar vermişlerse onlara bu yeni duruma ruhsal açıdan hazırlanabilecek yeterli zaman da kazandırılmış olmaktadır. Burada asıl olan boşanma konusunda tarafların duygusal faktörlerden uzak sağlıklı karar verebilmelerine imkan tanımaktır. Önerilen üç aşamalı boşanma sürecini psikolojik açıdan ele alanlar, bunu tarafların kısa süreli ayrılığı tecrübe etmesine olanak veren "terapötik (iyileştirici) ayrılık olarak" değerlendirmektedirler. ${ }^{17}$ Evlilik terapistleri, Kur'an'da boşanma sürecinde uygulanan iyileştirme amaçlı ayrılığı intiyaç duyulduğunda başvurulabilecek bir çözüm olarak da önermektedirler.

"Ey peygamber, kadınlarınızı boşayacağınızda onları iddete başlayabilecekleri bir zamanda boşayın ve iddeti sayın, Rabbiniz Allah'tan korkun. Bekleme süresi içinde onları evlerinden çıkarmayın, kendileri de çıkmasınlar. Ancak apaçık bir edepsizlik yapmaları durumu, bu hükmün dışındadır(o zaman evden çıkarabilirsiniz). Bunlar Allah'ın sınırlarıdır. Kim Allah'ın sınırlarını

16 Öfkeli şahsın talakını geçersiz görenlerin yanında; öfke durumunun aklı zedelemeyecek ölçüde olması halinde geçerli olacağını belirten âlimler olduğu gibi öfkelinin talakını mutlak anlamda geçersiz gören âlimler de vardır. Geniş bilgi için bkz. İbn Kayyim, I'lâmu'l- Muvakkîn an Rabbi'l-Âlemîn, Dâru'l-Kutübi'l-'illmiye, Beyrut 1996, c. IV, s. 40; İbn Âbidîn, Muhammed Emîn, Reddü'l-Muhtâr, Dâru Alemi'I-Kütüb, Riyad 2003, c. IV, s. 452; Zuhaylî, Vehbe, el-Fıkhu'I-Islâmî, Dâru'lFikr, Dımaşk 1989, c. VII, s. 364-365; Yaman, Ahmet, İslam Aile Hukuku, MÜ İlahiyat Fakültesi Vakfı Yayınları, İstanbul 2008, s.76; Erturhan, Sabri, İslâm Hukuku Açısından Öfkeli Şahsın Talakı, Cumhuriyet Üniversitesi Ilahiyat Fakültesi Dergisi, 2002, c. VI, sayı: 2, s. 207-222.

17 Bkz. Kasapoğlu, "Kur'an'da Terapötik Boşanma" Bilimname Dergisi, sayı, 9, 2005, s.77-78. 
geçerse kendine yazık etmiş olur. Bilmezsin belki de Allah, bundan sonra (iddet süresi içerisinde) bir iş ortaya çıkarır."18

Âyette geçen "leallellâhe yuhdisu ba'de zâlik emran" Bu süre içerisinde Allah bir iş ortaya çıkarabilir. Yani karı koca arasında bir uzlaşma, anlaşma fırsatı çıkarabilir. Üç ay gibi bir süre, kızgınlık ve benzeri birikimlerin etkilerini yok edebilir. Bu süre içerisinde Allah kalplerdeki hoşlanmama, düşmanlık ve husumeti çıkarıp, yerine ilgi sevgi ve şefkat koyabilir, böylece yeniden eşlerin birbirine dönmesi, evliliğin tekrar tesisi söz konusu olabilir. "Leallellâhe yuhdisu ba'de zâlik emran" ifadesi boşanma kesinleşmeden önce, bir uzlaşmanın ve böylece evlilik ilişkisinin yeniden sürdürülmesinin imkânına işaret eder. ${ }^{19}$

Âyette, kadınları iddet içinde boşamak ve iddeti saymak emredilmektedir. İddet kadının temizlik halinde bulunduğu yani adet görmediği durumdur. Müfessirlerin yorumuna göre, kadın hayızlı iken boşama yapılmaz; karısını boşamak isteyen kimse, onun adetten kesilmesini bekler, adet süresi sona erince henüz cinsel ilişkide bulunmadan onu boşar. Birinci ve ikinci boşamanın ardından kocanın eşine dönme hakkı vardır. En iyi/tutarlı boşanma biçimi olan bu boşanma şekli, "sünnî talâk" olarak adlandırılır. ${ }^{20}$

İddet süresi içerisinde boşama yapmanın birçok olumlu tarafı vardır. Her şeyden önce kadın hayız halinde değildir. Bu yüzden erkekle kadının birbirine cinsel yönden yaklaşmasında bir mani yoktur. Hayız halinde kadının ruh halinde olumsuz faktörler etkili olabilir. Bu da boşanma sürecini olumsuz yönde etkileyebilir. Oysa temizlik halinde yapılan boşamada böyle bir etki söz konusu olmaz. İddet süresine yayılan boşama eylemi, eşlere barışmak, anlaşmazlıkları gidermek, olumlu etkileşim ve iletişim kurabilmek için vakit kazandırır. ${ }^{21}$ Ayrıca boşanmanın kaçınılmaz olduğu durumlarda, eşlerin bir süre Mısır, 1987, c. XVIII, s. 104; el- Kâsımî, Muhammed Cemâlüddîn, Tefsîrü'l-Kâsımî, Dâru İhyâi't-Turâsi'l-Arâbî, Beyrut 1994, c. VII, s. 118; Yazır, Elmalıı Muhammed Hamdi, Hak Dini Kuran Dili, Eser Neşriyat İstanbul,1979, c. VII, s. 5065-5066; Bilmen, Ömer Nasuhi, Kur'ân-ı Kerim'in Türkçe Meâli Âlisi ve Tefsiri, Bilmen Yayınevi, İstanbul 1985, c. VIII, s. 3754; Ateş, Süleyman, Yüce Kur'ân'ın Çağdaş Tefsiri, Yeni Ufuklar Neşriyat, İstanbul 1991, c. IX. s. 483-484; Kasapoğlu, "Kur'an'da Terapötik Boşanma" s.78-79.

20 el-Kâsımî, Tefsîrü'l-Kâsımî, c. VII, s. 117; Bilmen, Kur'ân-ı Kerim'in Türkçe Meâli Âlisi ve Tefsiri, c. VIII, s. 3753; Ateş, Yüce Kur'ân'ın Çağdaş Tefsiri, c. IX. s. 483.

21 el-Mevdûdî, Ebu'l-A'lâ, Tefhîmü'l-Kur'ân, Çev. Muhammed Han Kayani ve Diğerleri, İnsan Yayınları, İstanbul 1989, c.VI, s.326. 
ayrı yaşamaları, boşanmaya hazırlık için iyi bir geçiş evresi sağlayabilir22 böylece boşanma taraflar için bir şok olmaktan çıkar.

Regl döneminde verilen talakın geçerliliğine gelince, bu konuda âlimler farklı düşünseler de bunun sünnete aykırı ve bid'at olduğu hususunda görüş birliği içindedirler. "Ey peygamber, kadınlarınızı boşayacağınızda onları iddete başlayabilecekleri bir zamanda boşayın ve iddetleri sayın."23 emri gereği sünnete uygun boşama, kadının hayız görmediği ve son regl dönemini müteakip içinde cinsel ilişkinin vuku bulmadığı temizlik döneminde bir talak şeklinde gerçekleşen boşamadır.

Rivayet edildiğine göre, Abdullah b. Ömer, hanımını, regl döneminde (hayızlı) iken boşamıştı. Bunun üzerine Hz. Ömer, bu durumu Resulullah'a (s.a.v) anlatmıştı. Resulullah (s.a.v), bu duruma kızmış, sonra da: O, hanımına geri dönsün. Hayızından temizlenip (tekrar) bir hayız (daha) görüp sonra (tekrar) temizleninceye kadar (hanımını nikâhı altında) tutsun. Eğer onu boşamak isterse, temizken (kendisiyle) cinsel ilişkide bulunmadan boşasın. İşte şanı yüce olan Allah'ın; kadınların içinde, boşanmasını emrettiği iddet (dönemi) budur" buyurmuştu. 24

Buna benzer bir rivayet daha var. Bu rivayetin içerisinde şu ifade yer almaktadır: "Ona emret! Hanımına geri dönsün. Ta ki kadın, içerisinde boşadığı hayız döneminden başka yeni bir hayız görene dek (onu nikâhı altında) tutsun. Eğer onu boşamak isterse, hayızından temizken (kendisiyle) cinsel ilişkide bulunmadan boşasın. İşte Yüce Allah'ın emrettiği iddet (dönemi) için boşamak, budur. ${ }^{25}$

Zikri geçen ayet (65/1) ve onun beyanı durumunda olan bu hadise göre regl döneminde gerçekleşen bir boşama tasvip edilmemekte hatta bazı

22 Tarhan, Nevzat, Kadın Psikolojisi, Nasıl Yayınları, İstanbul 2005, s. 245; Kasapoğlu, "Kur'an'da Terapötik Boşanma” s. 80. Talâk 65/1.

24 Buhârî, Talâk 2, 3; Müslim, Ebü'l-Hüseyin Müslim b. el-Haccac Sahîh-i Müslim, nşr. Muhammed Fuad Abdülbaki, Müessetü'l-Muhtar, Kahire 2010, Talâk 1-14 (1471); Ebû Dâvûd, Talâk 4 (2179, 2180, 2181, 2182, 2183, 2184, 2185\}; Tirmizî, Ebû İsa Muhammed b. İsa, Sünenü't-Tirmîzî, nşr. Ammar Tayyar ve dğr., Müessetü'rRisâle, Dimaşk 2011, Talâk 1 (1175); Nesâî, Ebû Abdurrahman Ahmed b. Ali, Kitab'üs-Süneni'l-Kübrâ, nşr. Hasan Abdülmünim, Müessetü'r-Risâle, Beyrut 2001, Talâk, 1, 3, 5; İbn Mâce, Talâk 3 (2023); Ahmed b. Hanbel, 2/74, 79 
âlimlerce haram olduğu belirtilmektedir. ${ }^{26}$ Nitekim eşini hayızlı iken boşayan kocanın talakı yukarıda geçtiği üzere bazı âlimlerce hukuken geçerli kabul edilse de; ahlaken (ya da diyaneten) onun karısına dönmesi gereği konusunda görüş birliği vardır. Ancak âlimler, kocanın karısına geri dönmesi bağlamında buna atfettikleri hüküm açısından (bu dönmenin vacip mi, ya da müstehap mı olduğu meselesinde) görüş ayrılığına düşmüşlerdir.

Mâlikîlere, bir rivayete göre Ahmed b. Hanbel'e, Şevkânî̀ye, ve Zâhirîlerden Dâvûd'a göre dönmesi vaciptir. Koca, hayız halinde boşadığı karısına dönmeye zorlanır. ${ }^{27}$

Ebû Hanife, İmam Şâfî, Evzaî, ibn Ebî Leylâ, Ebû Sevr, Ahmed b. Hanbel, İshak Kudûrî ile diğer bazı âlimlere göre, böyle durumda kocanın karısına dönmesi müstehaptır. Çünkü Hz. Peygamber'in İbn Ömer'e dönmesi için gıyabında verdiği emir, nedb ifade eder. Bu görüşü savunanlara göre, koca, karısına dönmeye zorlanamaz, ona dönmesi emredilir. ${ }^{28}$

Regl döneminde yapılan boşamanın bid'at ve ahlaken haram olduğu kabul edilmesine rağmen âlimlerin cumhuru bunun "bir boşama" şeklinde geçerli olduğu kanaatindedir. Nitekim Hanefî, Malikî, Şâfiî ve Hanbelîler bu görüşte olup onlara göre böyle bir boşama hukukî sonuçlar doğurur. ${ }^{29}$

Cumhur bu konuda delil olarak, talakla ilgili ayetlerin Kur'an'da mutlak olarak geçtiğini ve bir kayıt içermediğini ayrıca konuyla ilgili yukarıda zikri geçen rivayetin yanında "Abdullah ibn Ömer, hanımını bir talak ile boşamıştı. Bu da kadının talaklarından (bir talak) sayıldı. Bunun üzerine Abdullah, Resu-

26 İbn Hazm, Ebû Muhammed b. Ali b. Ahmed b. Saîd Zahiri, el-Muhallâ, nşr. Ahmed Muhammed Şakir, İdaretü't-Tıbaati'l-Müniriyye, Kahire, tsz., c. X, s.163; Kâsânî, Ebû Bekr 'Alâeddîn Ebû Bekr b. Mes'ûd b. Ahmed, Bedâi'u's-sanâi' fî tertîbi'şşerâi', Dâru'l-Kütübi'I-IIImiyye, Beyrut 1986, c. III, s. 88; İbn Kudâme, el-Muğnî, c. X, s. 329; Nevevî, Ebû Zekeriyyâ Muhyiddin Yahyâ b. Şeref b. Muri, el-Mecmû şerhu'l-Mühezzeb, thk. Muhammed Necîb Mut'î, Mektebetü'l-İrşâd, Cidde ts., c. XVIII, s. 216; İbn Kayyim, Zâdu'l-me‘âd, c. V, s. 219; İbn Hacer, Fethu'l-bârî, c. IX, s.351 Beyrut ts.; Zeydân, el-Mufassal, c. VIII, s. 96.

27 İbn Rüşd, Bidâyetü'l-Müctehid, Kahraman Yayınları, İstanbul, 1984; c. II, s.53-54; İbn Kudâme, el-Muğnî, VIII, 238-239; Nevevî, Ebû Zekeriyyâ Muhyiddin Yahyâ b. Şeref b. Muri , Şerhu Sahihi Müslim , c. X, s.60; Şevkânî, Ebû Abdullah Muhammed b. Ali, Neylü'l-evtâr min esrâri müntekâ'l-ahbâr, thk. Muhammed Subhî b. Hasen Hallâk, Dâru İbni'l-Cevzî, yy. 1427, c. XII, s.377-380.

28 Mergînânî, Ebü'l-Hasan Burhaneddin Ali b. Ebî Bekr, el-Hidâye Şerhu Bidâyeti'lMübtedi, nşr. Zalul Yusuf, Daru İhyaui't-Türasi'l-Arabi, Beyrut 1995, c. I, s. 228; İbn Rüşd, Bidâyetül-Müctehid, c. II, s. 53-55.

29 Mergînânî, el-Hidaye, c, I, s. 228; İbn Rüşd, Bidâyetü'l-Müctehid, c. II, s. 53-54; İbn Kudâme, el-Muğnî, c. VIII, s. 238-239. 
lullah'ın (s.a.v) kendisine emrettiği şekilde hanımına geri döndü" şeklinde rivayetlerin yer aldığını ileri sürerler. Ayrıca İbn Ömer için "eşine dönsün" ifadesinden hareketle "dönme" zikredildiğine göre boşama olmuştur şeklinde bir çıkarımda bulunurlar.

Zübeydî tarikiyle gelen benzer bir rivayette, Abdullah ibn Ömer şöyle der:

"Bunun üzerine eşime geri döndüm. Yapmış olduğum talak ise, kadın için bir talak sayıldı."30

Aralarında Saîd b. el-Müseyyeb'in de bulunduğu bazı tabiûn fakihleri, Câferü's-Sâdık, İmam Bâkır, İbn Hazm, İbn Teymiyye, İbn Kayyim elCevziyye, Şevkânî ${ }^{31}$ ve son dönem âlimlerden Muhammed Abduh, M. Reşid Rıza, Ebû Zehra ve Muhammed Şâkir gibi âlimlere göre, âdet halindeki kadının boşanması muteber olmaz ve hukukî sonuç doğurmaz. ${ }^{32} \mathrm{Bu}$ âlimlerin delileri de şöyledir:

“Ey peygamber! Kadınlarınızı boşayacağınızda onları iddete başlayabilecekleri bir zamanda boşayın ve iddetleri sayın."33 Bu ayette Yüce Allah iddetin sayılabileceği bir dönemde yani temizlik döneminde boşamayı emretmiş ve bunu esas kılmıştır. Bunun dışında vâki olan talak muteber değildir. Ayrıca bu ayet talakla ilgili diğer nassların mutlak ifadelerini kayıtlamaktadır. Dolayısıyla erkeğin karısının iddetini gözetmeden boşaması muteber olmaz.

Allah'ın emrettiği iddetin mahiyeti, Hz. Peygamber'in Abdullah'dan dolayı babası Hz. Ömer'e söylediği “ $O$, hanımına geri dönsün. (Hayızından) temizlenip (tekrar) bir hayız (daha) görüp sonra (tekrar) temizleninceye kadar (hanımını nikahı altında) tutsun. Eğer onu boşamak isterse, temizken (kendisiyle) cinsel ilişkide bulunmadan boşasın. İşte şanı yüce olan Allah'ın; kadınların, içinde boşanmasını emrettiği iddet (dönemi) budur" sözü ile beyan olunmuştur.

30 Müslim, Talak 4 (1471).

31 Gerçi Şevkânî es-Seylü'l-cerrâr adlı eserinde bunun aksi görüşe meyleder. Bkz. Şevkânî, es-Seylü'l-cerrâr, c. II, s. 348.

32 el-Hattâbî, Meâlimu'Sünen Şerhu Süneni Ebî Dâvûd, c. III, s. 201; İbn Hazm, elMuhallâ, c. XI, s. 449; Kurtubî, Ebû Abdullah Muhammed b. Ahmed el-Ensârî , elCâmi' li-Ahkami'l-Kur'ân, Mısır, 1987, c. XVIII, s.152; İbn Teymiyye, Takıyyüddin elFetâvâI-Kübrâ, Beyrut, 1987 . c. III, s.16; İbn Kayyim, Zâdu'l-Meâd, c. V, s. 218225; Şevkânî, Neylü'l-Evtâr, c.VI, s. 224-226; Ebû Zehrâ, el-Ahvâlü'ş-Şahsiyye, Kahire, tsz, s. 287-288; Reşid Rıza, Hukuku'n-Nisâ fi'l-İslâm, tsz, s. 170 ; Şâkir, Ahmed Muhammed, Nizâmu't-talâk fî̀-IIslâm, Mektebetü's-Sünne, yy. ts. s. 19.

Talak, 65/1. 
Kur'ân'da "Boşama iki defadır."34 buyrulmaktadır. Bu ayette Allah, izin verilen ve pişmanlık durumunda dönüşü mümkün olan talakı iki ile sınırlandırmıştır. Ayette geçen "merretân" lafzına göre boşama bir defada iki kere değil, bir boşamadan sonra diğer bir temizlik döneminde ikinci bir boşama şeklinde olmalıdır. Bunun dışındakiler talak değildir. Sahabe de bu şeklin dışında gelişen talakı haram olarak görmüştür.

\section{Değerlendirme ve Sonuç}

Hz. Peygamber'in, "Bizim dinimize uygun olmayan her iş merduttur/reddolunur." ${ }^{5}$ hadisi Allah ve Rasulünün emri, talebi ve izni dışında gerçekleşen bir talakın geçersiz sayılacağı noktasında önemli bir delil teşkil eder. Çünkü regl döneminde gerçekleşen boşama, Hz Peygamberin boşanmaya dair belirlediği usulün dışında kalmaktadır.

Netice itibarıyla bakıldığında kadınları regl döneminde boşamanın muteber olmadığını savunanların görüşlerinin daha isabetli ve delilerinin daha güçlü olduğu görülür. "Kadınlarınızı boşayacağınızda onları iddete başlayabilecekleri bir zamanda boşayın ve iddetleri sayın."36 emrinin istihbab veya nedb ifade ettiğine dair bir karine olmadığına göre bunun vücub ifade ettiği açıktır. Dolayısıyla bu emre aykırı hayız döneminde yapılan bir boşama geçersiz olacaktır. Her iki taraf İbn Ömer hadisini delil olarak kullansa da "o karısına dönsün" ifadesi bu boşamanın geçerli olmadığını gösterir. ${ }^{37}$

Hayız döneminde yapılan boşamanın tasvip edilmemesinin hikmetine gelince, âlimler, boşamanın vaki olduğu hayız günlerinin iddetten sayılmaması nedeniyle iddetin uzayacak olması şeklinde açıklamışlardır. Bu noktada regl dönemindeki kadınların halet-i ruhiyelerinin, bir diğer ifade ile psikolojik durumlarının dikkate alınması meselesine temas edilmemiştir. Oysa kadınların çoğunlukla âdet dönemlerinde hormonal olarak bir kısım değişikliklere maruz kalmaları, bünyelerinde meydana gelen fizyolojik değişiklikler ve aybaşı sendromu etkisiyle normal durumlarda göstermeyecekleri tutum ve davranışlarda bulunmaları muhtemeldir. Bu dönemde gerçekleşen yoğun hormonal değişiklikler sebebiyle kadınlar bazen aşırı duygusal, bazen aşırı öfkeli, bazen ise aşırı kaygılı hissederler ve bu duygu halleri davranışlarına da yansıyabilir. Bu

34 Bakara, 2/229.

35 Buhârî, l'tisâm, 20; Sulh 5; Ebû Dâvud, Sünnet, 5.

36 Talak 65/1.

37 Tartışmalarla ilgili geniş bilgi için bkz. Acar, H. İbrahim, İslam Hukukunda Evliliğin Sona Ermesi, Ekev Yayınları, Erzurum, 2000, s.77-92. 
sebeple, bu dönemde dikkat edilmesi gereken en hassas konulardan biri de ilişkilerdir. Erkekler bu dönemlerde kadınların hormon seviyelerinde oluşan değişikliklerden haberdar olmadıklarından kadınların aşırı duygusallığını ve sürekli değişen ruh hallerini yanlış yorumlayabilirler. Bu konu ile ilgili bilgi eksikliği yanlış değerlendirmelere yol açabildiğinden kadınların bu dönemlerinde ilişkilerinin yıpranma olasılığı oldukça yüksektir. ${ }^{38}$

Kadın, içsel değişikliklerin yanı sıra bu dönemde bazı fiziksel değişikliklere de uğrar. Vücut su toplar ve şişer. Yüzde ve vücutta akneler oluşur. Bazen aşırı terleme de görülebilir. Hem değişen hormon seviyeleri hem de fiziksel özellikler sebebiyle kadın normalde olduğundan daha kötü bir görünüşe sahip olduğuna inanır ve kendini değersiz hissetmeye başlar. ${ }^{39}$

İlişkilerde yaşanan sorunlar ve kadının kendi hakkındaki olumsuz algıları birleşince depresyona kadar varabilecek durumlar ortaya çıkabilir.

Bu şekilde tezâhür eden geçimsizlik haline duygusal faktörler karışmış olacaktır. Neticede kadının bu psişik hali, boşanma sürecini olumsuz etkileyecektir. Kulunun maddi-manevi her türlü maslahatını gözeten Yüce Şâri, "Sana kadınların özel hallerini sorarlar. De ki o bir sıkıntı/ rahatsızlıktır, bu nedenle ay halinde olan kadınlardan uzak durun"40 buyurarak bu durumdaki kadınlarla ilişki/iletişimde daha dikkatli davranılmasını öğütlemektedir. Hayızın ezâ olduğunu bildiren bu ayet iki yönlü olarak anlaşılabilir. Birincisi, hayız halini yaşamanın kadın için bir eziyet olması durumudur. İkincisi ise, hayız halinde cinsel ilişkinin hem erkeğe hem de kadına vermiş olduğu eziyettir. ${ }^{41}$ Bu nedenle ayette "uzak durmadan" maksadın cinsel ilişki olduğu bir gerçektir. Bununla birlikte, onlarla olan diyalogda duyarlı davranılması gerektiği anlamı da ayetin zımnında mevcuttur.

Ezâ kelimesinin Kur'an'da farklı yerde kullanıldığı anlamlar, ruhsal ve bedensel açıdan duyulan acıyı, çekilen sıkıntıyı, yaşanılan rahatsızlığı anlat-

38 Markham, Ursula, Kadınlar Için Stres El Kitabı, Çev. Türkan Tezcan, Alfa/Aktüel Kitabevleri, İstanbul 1993, s.71; Saygılı, Sefa, Yaşam ve Cinsellik, Mozaik Yayınları, İstanbul 2004, s.33-34.

39 Horney, Karen, Kadın Psikolojisi, Çev. Selçuk Budak, Öteki Yayınevi, Ankara 1995, s.102.

40 Bakara, 2/222

41 Kasapoğlu, Kur'an’a Psikolojik Yöneliş Evlilik ve Aile, Kendini Bilmek Yayınları, Malatya 2013, s.109. 
maktadır. ${ }^{42} \mathrm{Bu}$ anlatımlarla hayız halindeki kadının yaşadıklarının "ezâ" olarak nitelenmesi arasında anlamlı bir ilişki vardır. ${ }^{43}$ Çünkü ayette yer alan ezâ kelimesi fizyolojik rahatsızı̆ğı içine aldığı gibi psikolojik sıkıntıları da içerir. Nitekim sıkıntı kapsamında birçok kadında regl döneminde agresiflik, gerilim, ağlamaklık vb. şekilde seyreden duygu durum bozuklukları, günümüz tıp biliminde Premenstrüel disforik sendrom olarak isimlendirilmiştir. ${ }^{44}$ İşte Kur'an'ın bu zikredilen psikolojik rahatsızlıkları içeren sendromu isimlendirmese de, o çağda vaz ettiği hükümlerde bunu gözetmiş olması dikkat çekicidir.

Netice olarak öfke anında insanın mantıklı düşünme yeteneğinin geçici olarak bloke olması ve akl-ı selim düşünme sürecinin oluşumunun sekteye uğraması nedeniyle, Hz. Peygamber, "Hiç bir hâkim öfkeli haldeyken hüküm veremez/ vermesin" buyurarak hakimin öfkeli iken yargılama yapmasını yasaklamıştır. İslâm hukukçuları da zikredilen bu hadisi delil alarak, öfkeli hale ilaveten hâkimin şiddetli açlık, susuzluk, uykusuzluk, üzüntü, hastalık ve sair durumlarda da hüküm vermesinin uygun olmayacağı sonucuna ulaşmışlardır. Bu itibarla hâkimin, yargılama faaliyetinde bulunacağı zaman, mutedil ve sakin bir halde olması, adil bir karar verebilmesinin hikmeti olarak değerlendirilmiştir. Dolayısıyla onun sağlıklı düşünüp doğru karar vermesine engel olacak her türlü psikolojik etmenlerden uzak bulunması gereğine işaret edilmiştir.

Aynı şekilde Hz. Peygamber, "Iğlak/aşırı öfke halinde boşama ve azad yoktur" buyurarak sinir krizi halindeki öfkeli şahsın da talakının geçersiz olduğuna işaret etmiştir. Hadiste geçen "iğlak" kelimesini, bazı âlimler ikrah olarak anlasalar da âlimlerin kahir ekseriyeti "gazap" olarak tefsir etmiştir. "Iğlak" teriminin, kapamak ve kilitlemek anlamını muhtevi olması nedeniyle; öfkeli şahsın salim düşünme kapısının kapanacağı ve psikolojik olarak onun

42 Ezânın farklı anlamları için bkz. Bakara, 2/196,22; Âl-i İmrân, 3/195; Nisâ, 4/16, 102; Tevbe, 9/61; Ahzâb, 33/53,69; İbrahi, 4/14.

43 Kasapoğlu, Kur'an’a Psikolojik Yöneliş Evlilik ve Aile, s.105.

44 Kadınlarda her ayın yaklaşık dörtte birini kapsayan, adet döneminden önce ve adet dönemi sırasında görülen ve bazı duygusal, davranışsal ve somatik (fiziksel) semptomları kapsayan dönemler 'Adet Dönemi Ruhsal Sorunları (premenstrüel sendrom)' olarak adlandırılır. Eğer bu dönemde yaşanılan çeşitli semptomlar günlük yaşantının gidişatını bozacak derecede ise buna premenstrüel disforik bozukluk adı verilir. Adet dönemi (Premenstrüel) semptomları ortalama olarak kadınların \%70'inde görülürken, premenstrüel disforik bozukluk toplumun çok az bir kısmında görülür. Bu bozukluk, psikiyatrik tanı kitabı olan DSM-IV'te duygu-durum bozukluğu olarak kategorize edilmiştir. Bkz. Özkan, Sedat, Psikiyatrik Tıp, Roche Yayını, İstanbul 1993, s. 217; Markham, Ursula, Baskı Altındaki Kadın, Çev. Murat Sağlam Alfa/Aktüel Kitabevleri, İstanbul 1999, s. 130. 
sağlıklı karar veremeyeceği düşünülmüştür. Bu nedenle öfkeli şahsın talakı da âlimlerin önemli bir kısmı tarafından geçersiz kabul edilmiştir.

Hâkimin öfkeli iken ve bazı olumsuz psikolojik hallerinin yargı faaliyetine olumsuz yansımaması noktasında gözetilen makâsıd, öfkeli iken talak tasarrufunda bulunan kimsenin tasarrufunun geçerli olmaması noktasında da gözetilmiştir. Regl döneminde yapılan boşamanın, İbn Ömer hadisinde olduğu gibi, geçersiz kabul edilmesi; bunun sünnete aykırı bid'at bir uygulama olarak değerlendirilmesinde de aynı hikmet ve makâsıd gözetilmiştir.

Kadınların özel hallerinden bahseden ayette yer alan "ezâ" kelimesinin fizyolojik rahatsızlığı içine aldığı gibi birçok psikolojik sıkıntıları da içermesi nedeniyle, bu regl döneminde yapılan boşamanın Şâriin gözettiği hikmet ve makâsıda aykırı olacağı bir gerçektir. O halde bu meseleyle alakalı olarak günümüzde, regl döneminde kadının içinde bulunduğu halet-i ruhiyenin ve bunun muhtemel olumsuz etkilerinin izahının, bilimsel veriler ışığında daha kolay yapılacağından; bu dönemde ondan ayrılmanın ve onu boşamanın uygun olmayacağı daha anlaşılır hale gelmiştir.

Şâri'in koyduğu hükümlerdeki hikmeti, bu örneklerde olduğu gibi gelişen bilimin ışığında yeniden düşünmek ve araştırmak Müslüman âlimler için büyük önemi haizdir. Bu, İslam hukukunun vahiy kaynaklı ve hikmeti gözeten bir karaktere sahip olmasının ürünüdür/ semeresidir. 


\section{Kaynakça}

Acar, H. İbrahim (2000), İslam Hukukunda Evliliğin Sona Ermesi, Erzurum: Ekev.

Ahmed Abdurrahman (2006) , Kızma, Çev. Seyfullah Erdoğmuş, İstanbul: Polen Yayınları,

Ahmed b. Hanbel, Ebû Abdullah Ahmed b. Muhammed eş-Şeybânî (1995), elMüsned, XV nşr.: Şuayb el- Arnaût, Beyrut: Müessesetü'r-Risâle.

Aslan, Nasi, (2014)İslam Hukukunda Yargılama Etiği İlkeleri, Adana: Karahan Kitabevi.

Ateş, Süleyman, (1991), Yüce Kur'ân'ın Çağdaş Tefsiri, İstanbul: Yeni Ufuklar Neşriyat.

Aydın, Hayati (1999), Kur'an'da Insan Psikolojisi, İstanbul: Timaş Yayınları.

Bilmen, Ömer Nasuhi (1970), Hukuk-i İslamiye ve Istılah-ı Fıkhiye Kamusu, İstanbul: Bilmen Yayınları.

--------, (1985), Kur'ân-ı Kerim'in Türkçe Meâli Âlisi ve Tefsiri, İstanbul: Bilmen Yayınevi.

Buhârî, Ebû Abdullah Muhammed b. İsmail (2010), Sahîhu'l-Buhârî, nşr. Halil b. Me'mun Şiha Beyrut: Dâru'l-Marife.

Dârekutnî, Alî b. Ömer (2004), Sünenü'd-Dârekutnî, thk. Şu'ayb el-Arnavut ve dğr. Beyrut: Müessesetü'r-Risâle.

Ebû Dâvûd, Süleyman b. Eş'as es-Sicistânî (1997), Sünenü Ebî Dâvûd, nşr. İzzet Ubeyd ed-De'as, Muhammed Ali es-Seyyid, Beyrut: Dâru İbn Hazm.

Ebû Zehrâ, Muhammed (tsz.), el-Ahvâlü'ş-Şahsiyye, Kahire: yy.

Erturhan, Sabri, (2002), İsıâm Hukuku Açısından Öfkeli Şahsın Talakı, Cumhuriyet Üniversitesi İlahiyat Fakültesi Dergisi, , c. VI, sayı: 2, ss. 207222

Halil, Ebû Abdirrahmân b. Ahmed b. Amr b. Temim el-Ferâhidî (el-Fürhûdî), (2000) Kitâbü'l-ayn, thk. Abdulhamîd Hindâvî, Beyrut: Dâru'l-Kütübi'lİlmiyye.

Hattâbî, Ebû Süleyman Hamd b. Muhammed b. İbrâhim (tsz.), Meâlimü'sSünen Şerhu Süneni Ebî Dâvûd, nşr. Muhammed Râgıb et-Tabbâh, Haleb: Matbaatü'l-IIImiyye.

Horney, Karen, (1995), Kadın Psikolojisi, Çev. Selçuk Budak, Ankara: Öteki Yayınevi.

İbn Âbidîn, Muhammed Emîn, (2003), Reddü'l-Muhtâr, Riyad: Dâru Alemi'lKütüb. 
İbn Hacer, Ebü'l-Fazl Şehabeddîn Ahmed Askalânî, (2001), Fethu'l-bârî bişerhi Sahîhi'l-Buhârî, thk. Abdulkâdir Şeybe Hamdî, Riyâd: Mektebetü'I-Mülük Fehdü'l-Vatanî,

İbn Hazm, Ebû Muhammed b. Ali b. Ahmed b. Saîd Zahiri, (tsz.), el-Muhallâ, nşr. Ahmed Muhammed Şakir, Kahire: Idâretü't-Tıbâati'I-Münîriyye.

İbn Kayyim, Ebû Abdullah Şemseddin Muhammed, (1994) Zâdu'l-Meâd fi Hayri'l-Ibâd, nşr. Şuayb el-Arnaût, Kuveyt: Mektebetü'l-Menâri'lİslâmî.

, (1996), I'lâmu'l- Muvakkîn an Rabbi'l-Âlemîn, Beyrut: Dâru'l-Kutübi'l'Illmiye.

İbn Kudâme, Ebû Muhammed Muvaffakuddîn Abdullah b. Ahmed (1999), elMuğnî, nşr. Abdullah b. Abdülmuhsin Türkî, Abdülfettâh Muhammed el-Hulv, Riyad: Dâru Âlemi'l-Kütüb.

İbn Mâce, Ebû Abdullah Muhammed b. Yezid (2009), Sünenü Ibn Mâce, nşr. Ammâr Tayyâr, Yâsir Hasan, Dimaşk: Müessetü'r-Risâle.

İbn Mâze, Hüsamüddîn (1977), Kitâbu Şerhi Edebi'l-Kâdî li'l-Hassâf, Bağdat: y.y.

İbn Rüşd, Ebü'l-Velîd Muhammed b. Ahmed b. Muhammed Kurtubî (1997), Bidâyetü'l-müctehid ve nihayetü'l-muktesıd, nşr. Abdülmecid Tu'me Halebî, Beyrut: Dârü'l-Ma'rife.

İbn Teymiyye, Takıyyüddin (1987), el-FetâvâI-Kübrâ, Beyrut: Dâru'I-Kütübü'lIIlmiyye.

Kâsânî, Ebû Bekr 'Alâeddîn Ebû Bekr b. Mes'ûd b. Ahmed, (1986), Bedâi'u'ssanâi' fî tertîibi'ş-şerâi', Beyrut: Dâru'l-Kütübi'l-IImiyye.

el-Kâsımî, Muhammed Cemâlüddîn, (1994) Tefsîrü'l-Kâsımî, , Beyrut: Dâru İhyâi't-Turâsi'l-Arâbî.

Kasapoğlu, Abdurrahman, (2012) “Kur'an'da Adalet Psikolojisi-Adaleti Engelleyen Psiko Sosyal Faktörler" Hikmet Yurdu Dergisi, www.hikmetyurdu.com- sayl: 10, 2012, ss.61-105.

, (2005) “Kur'an'da Terapötik Boşanma” Bilimname Dergisi, sayı, 9, ss.75-87.

, (2013), Kur'an'a Psikolojik Yöneliş Evlilik ve Aile, Malatya: Kendini Bilmek Yayınları.

Kelvezânî, Mahfuz b. Ahmed (2002), el-Hidâye fî Furûi'l-Fıkhi'l-Hanbelî, Beyrut: Dâru'l-Kütübi'l-IIlmiyye.

Kurtubî, Ebû Abdullah Muhammed b. Ahmed el-Ensârî (1987), el-Câmi' li ahkâmi'l-Kur'ân, Mısır: Dâru Âlemi'I-Kütüb. 
Markham, Ursula, (1993), Kadınlar İçin Stres El Kitabı, Çev. Türkan Tezcan, İstanbul: Alfa/Aktüel Kitabevleri.

---------, (1999), Baskı Altındaki Kadın, Çev. Murat Sağlam, İstanbul: Alfa/Aktüel Kitabevleri.

Merğinânî, Ebü'l-Hasan Burhaneddin Ali b. Ebî Bekr (1995), el-Hidâye Şerhu Bidâyeti'l-Mübtedi, nşr. Za'lûl Yûsuf, Beyrut: Dâru İhyâi't-Türâsi'lArabî.

el-Mevdûdî, Ebu'l-A'lâ, (1989), Tefhîmü'l-Kur'ân, Çev. Muhammed Han Kayani ve Diğerleri, İstanbul: İnsan Yayınları.

Müslim, Ebü'l-Hüseyin Müslim b. el-Haccac (2010), Sahîhu Müslim, nşr.: Muhammed Fuad Abdülbaki, Kahire: Müessesetü'l-Muhtâr.

Nesâî, Ebû Abdurrahman Ahmed b. Ali (2001), Kitabü’s-Süneni'l-Kübrâ, nşr.: Hasan Abdülmün'im, Beyrut: Müessesetü'r-Risâle.

Nevevî, Ebû Zekeriyyâ Muhyiddin Yahyâ b. Şeref (1972), Şerhu Sahihi Müslim, Beyrut: Dâru İhyâi't-Türâsi'l-Arabî.

--------, (ts.), el-Mecmû' şerhu'l-Mühezzeb thk. Muhammed Necîb Mut'î, Cidde: Mektebetü'l-İrşâd.

Özkan, Sedat, (1993), Psikiyatrik Tıp, , İstanbul: Roche Yayını.

Rıza, Muhammed Reşit (1985), Hukuku'n-nisâ fi'l-İslâm, Kahire: Mektebetü'tTürâsi'l-İslâmî.

Saygılı, Sefa, (2004), Yaşam ve Cinsellik, İstanbul: Mozaik Yayınları.

Şâkir, Ahmed Muhammed, (ts.), Nizâmu't-talâk fi'l-İslâm, yy.: Mektebetü'sSünne.

Şevkânî, Ebû Abdullah Muhammed b. Ali (1427), Neylü'l-evtâr min esrâri müntekâ'l-ahbâr, thk. Muhammed Subhî b. Hasen Hallâk, yy., Dâru İbni'l-Cevzî.

---------, (ts.), es-Seylü'l-cerrâri'l-mütedaffik 'alâ hadâiki'l-ezhâr, thk. Mahmûd İbrâhîm Zayed, Beyrut: Dârü'l-Kütübi'l-İlmiyye.

Tarhan, Nevzat, (2005), Kadın Psikolojisi, İstanbul: Nasıl Yayınları.

Tirmizî, Ebû Îsâ Muhammed b. İsa (2011), Sünenü't-Tirmizî, nşr.: Ammâr Tayyâr ve dğr. Dimaşk: Müessesetü'r-Risâle.

Yaman, Ahmet, İslam Aile Hukuku, (2008) İstanbul: MÜ İlahiyat Fakültesi Vakfı Yayınları.

Yazır, Elmalılı Muhammed Hamdi. (1979), Hak Dini Kuran Dili, İstanbul: Eser Neşriyat.

Zeydân, Abdulkerîm (1993), el-Mufassal fî ahkâmi'l-mer'e ve'l-beytü'l-müslim fi'ş-şerî‘ati'l- İslâmiyye, Beyrut: Müessesetü'r-Risâle.

Zuhaylî, Vehbe, (1989) el-Fıkhu'l-Islâmî, Dımaşk: Dâru'l-Fikr. 


\section{Psychological Factors in Hadiths of Statutes: A Review on Divorce in Period of Menstruation}

Citation / @-Aslan, N. (2017). Psychological Factors in Hadiths of Statutes: A Review on Divorce in Period of Menstruation, Çukurova University Journal of Faculty of Divinity, 17 (1), 21-38.

Abstract: The religion of Islam, sent by Allah in order to lead people into the right way for their bliss in life and in the afterlife, has considered wisdom, through the provisions that are laid out. Due to this wisdom, while giving people responsibilities, all the material and moral aspects of the addressee have been taken into consideration. The chief moral aspect of the indivual and the one that even forms his/her point of view to events is his/her psychology. Since Qur'an is revealed considering the human physcolog, the prophet has not ignored this aspect in hadiths. Our prophet indicates a principle that must be followed by the judge before judging in one of his hadiths saying " a judge must not / cannot judge when he is angry". This principle is that the judge does the judging when he is calm and nonchalant, in other words when he is not under the influence of some emotions. Judging from the hadiths above, as, proof to the hadith that is recited, the islamic jurists have expressed that in addition to anger, it is not appropriate for a judge to do the judging in an occasion of strong hunger, thirst, sleeplessness, ilness and sadness. The same factors that are taken into consideration to prevent a judge's some negative psychological moods from influencing his judging are taken into account, as well, to take a husband's decision of divorce as invalid if he has made that decision when he is not psychologically well. Here, it's clear that there are intentions of that Muslim scholars having a dispute with the validity of the divorce in the menstruation period but agreeing that this divorce is a bidah that is against sunnah. The examples, of which the psychological conditions of the women are taken into consideration whilst judging on the situations peculiar to them, have been discussed in this article (their mens, etc.).

Keywords: Hadiths of statutes, psychological factor, divorce, menstrual period, iddet(waiting period), wisdom 